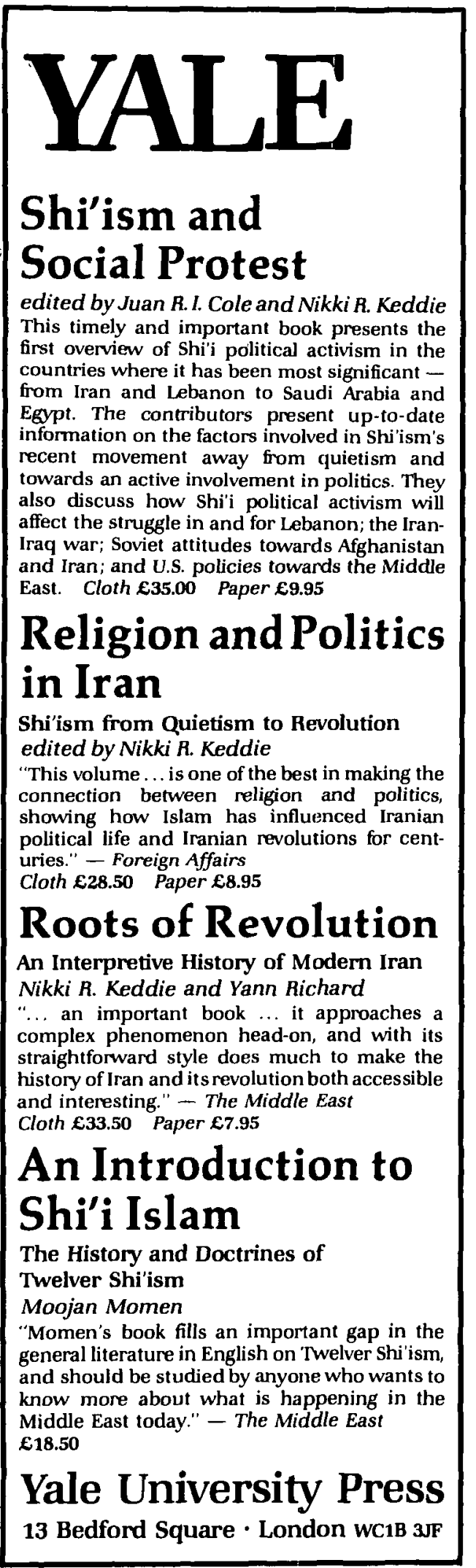




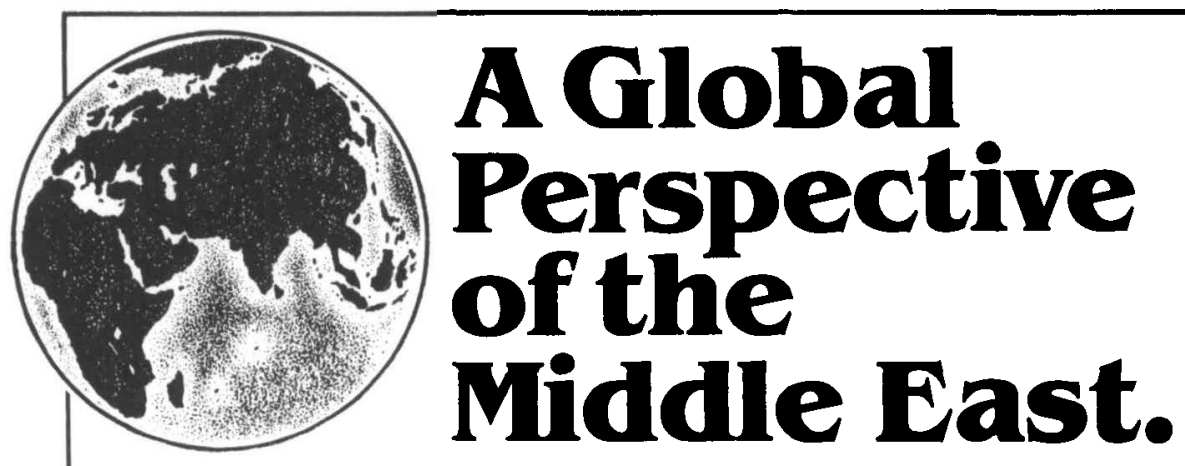

\section{Under Siege}

P.L.O. Decisionmaking During the 1982 War

\section{Rashid Khalidi}

"An extremely valuable analysis of why the P.L.O. made the decisions it did during that fateful summer.... For students of the Middle East, his generally objective, lucid and incisive account fills a critical void in the literature about the Israeli invasion."

-The New York Times Book Review

232 pp., $\$ 25.00$

\section{Islam Assembled}

The Advent of the Muslim Congresses

\section{Martin Kramer}

A pathbreaking study that traces the roots of political activism in Islam. Kramer probes the history of Muslim congresses from the late nineteenth century to the postwar era of independence. Dayan Center for Middle Eastern and African Studies 288 pp., $\$ 30.00$

\section{Women in Saudi Arabia}

Ideology and Behavior Among the Jiddah Elite

\section{Soraya Altorki}

A unique view of Saudi Arabian urban society - written by a Saudi-that studies change over three generations of elite women in the city of Jiddah. 224 pp., $\$ 30.00$

\section{Iraq Between the Two} World Wars

The Creation and Implementation of a Nationalist Ideology

Reeva S. Simon

Explains modern Iraqi history in terms of cultural and ideological factors, as opposed to a class theory analysis. Simon discusses the influence of the German model of nationalism upon modern Arab nationalism.

256 pp., $\$ 30.00$

\section{Now in paperback}

\section{"The Government of God"}

Iran's Islamic Republic

Cheryl Benard and Zalmay Khalilzad

"The authors have tackled a complex subject and they have raised important theoretical issues and offered insights into the Islamic Republic."

-MESA Bulletin

$240 \mathrm{pp}$., line drawings, $\$ 12.50 \mathrm{pa}$

To order, send check or money order to Dept. JN at the address below, including $\$ 2.00$ for postage and handling.

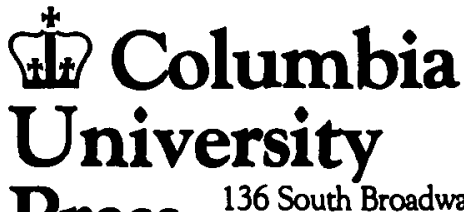
Dress 136 South Broadway 


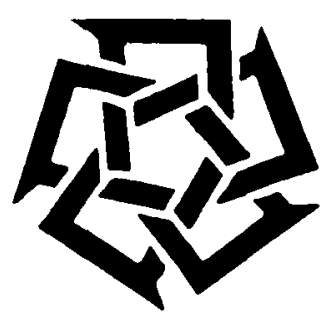

\section{THE AMIERICAN UNIVERSITY IN CAIRO PRESS}

Columbia University Press is pleased to distribute books from The American University in Cairo Press. One of the Middle East's foremost academic presses, Cairo gives both specialists and lay readers the best and latest materials for understanding Egypt and the Arab world.

\section{The Islamic Monuments of Cairo: Third Edition}

A Practical Guide

Richard B. Parker and Robin Sabin; revised and updated by Caroline Williams.

Discusses the major monuments of Cairo's rich Islamic architectural heritage, describing the ciry's development from 640 A.D.

Illus., maps, $\$ 12.50$

\section{The Minarets of Cairo}

Doris Behrens-Abouseif. Describes the development of the minaret from its earliest stages through the Ottoman Period.

203 pp., 160 lllus., $\$ 15.00$

\section{Great Cairo}

\section{Mother of the World}

Desmond Stewart. Details Cairo's long, romantic history as a political and cultural center. 226 pp., Illus. $\$ 15.00$

\section{A Bibliography of the Architecture, Arts and Crafts of Islam \\ Second Supplement: January 1972 to December 1980}

J.D. Pearson; assisted by Michael Meinecke and George Scanlon. An updating of K.A.C. Creswell's monumental work begun in 1912 , covering all aspects of Islamic architecture. 578 pp., $\$ 70.00$

\section{The Fayoum}

A Practical Guide

R. Neil Hewison. A general guide reflecting the author's experiences of living and working in the Fayoum for three years. 160 pp., Illus., Maps, $\$ 12.50$
Now in paperback

\section{The Thief and the Dogs}

Naguib Mahfouz; translated by M.M.

Badawi and Trewor Le Gassick; revised by John Rodenbeck. A thriller about a professional thief and would-be killer whose adventures carry him to the heights and depths of Cairo society during the revolution. 108 pp., $\$ 5.95$ pa

\section{Autumn Quail}

Naguib Mahfouz. Set around the time of the Egyptian revolution, this story reveals the prevailing political attitudes. $\$ 5.95$ pa

\section{The Obelisks of Egypt}

Skyscrapers of the Past

Labib Habachi. The former Chief Inspector of Antiquities of Egypt gives a thorough account of one of ancient Egypt's most prolific architectural forms: the obelisk.

204 pp., Illus. $\$ 15.00$ pa

\section{The Egypt Story}

Its Art, Its Monuments, Its People, Its History

Photographs by Fred J. Maroon; text by P.H. Newby. A lavishly illustrated pictorial record that spans the 5,000 year civilization of Egypt. 259 pp., 180 color photos, $\$ 24.50 \mathrm{pa}$

To order, send check or money order to Dept. $\mathrm{JN}$ at the address below, including $\$ 2.00$ for postage and handling.

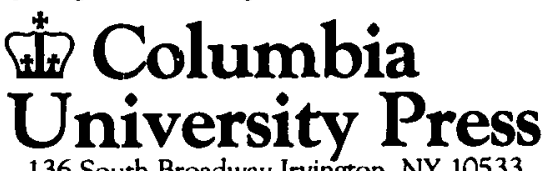

136 South Broadway Irvington, NY 10533 


\section{Syracuse \\ Contemporary Issues in the Middle East}

\section{Women in Egyptian Public Life}

Earl L. Sullivan

Egypt is the most progressive of all the Arab countries, a fact reflected in the role and position of women. Sullivan discusses women in partiament (more than in either the U S Congress or the Israeli Knesset), the political opposition, and business, as well as the wives of Egypt's presidents-Sullıvan interviewed Jihan Sadat and Suzanne Mubarak for this book.

248 pages, index

Cloth $\$ 29.95$

\section{Development and Social Change in Rural Egypt}

Richard H. Adams, Jr.

Adams spent nearly two years living and working with peasant farmers and agricultural officials in two villages in upper and lower Egypt. His findings reveal that the Egyptian government's planned rural reform program has been far from a success.

造 248 pages, 27 illus., 29 tables, index Cloth 82995

\section{Women Farmers in Africa}

\section{Rural Development}

in Mali and the Sahel

\section{Edited by Lucy E. Creevey}

Foreword by Ruth S. Morgenthau

"Fills a real need. An unusual and valuable contribution to the literature on women in rural development "- Barbara Lewis,

Rutgers University

Many of the eleven essays in this collection are by African women in charge of ongoing projects in Mali and Upper Volta and thus provide first-hand accounts of the women farmers and the various programs trying to assist them.

\footnotetext{
232 pages, 14 tlus, map, index

Cloth \$29 95 Paper $\$ 14.95$
}

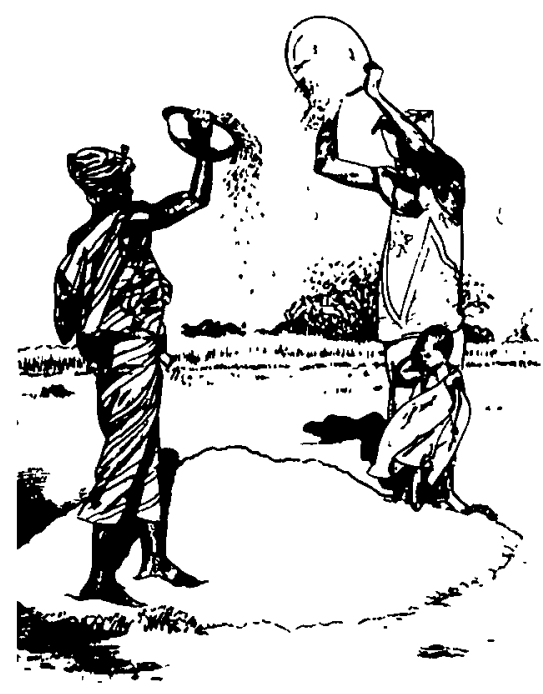

\section{The Maronites in History}

Matti Moosa

The first history of this key Middle East community Moosa begins with the early roots of the Maronite Church in fifth-century Syria and traces its development and evolution to an examinat on of the Maronite community's role in today's civil strife in Lebanon and the . relationship with their Muslim and Druze neighbors. This is certain to become a standard work and will be of interest to all Middle East scholars.

352 pages, index Cloth $\$ 3500$

Now in their second print ings....

\section{Islam in Revolution}

Fundamentalism in the Arab World
R. Hrair Dekmejian
Cl $\$ 26 \quad$ Paper $\$ 1295$

\section{The Arab-Israeli Dilemma, 3rd Edtion}

Fred J. Khouri

Cl $\$ 1995 \quad$ Paper $\$ 12.95$

Syracuse University Press 1600 Jamesville Avenue, Syracuse, New York 13244-5160 


\section{ENGLISH TRANSLITERATION SYSTEM}

\section{CONSONANTS}

Columan Headings: $\mathbf{A}=$ Arabic, $\mathbf{P}=$ Persian, OT $=$ Ottoman Turkish, $\mathbf{M T}=$ Mlodern Turkish

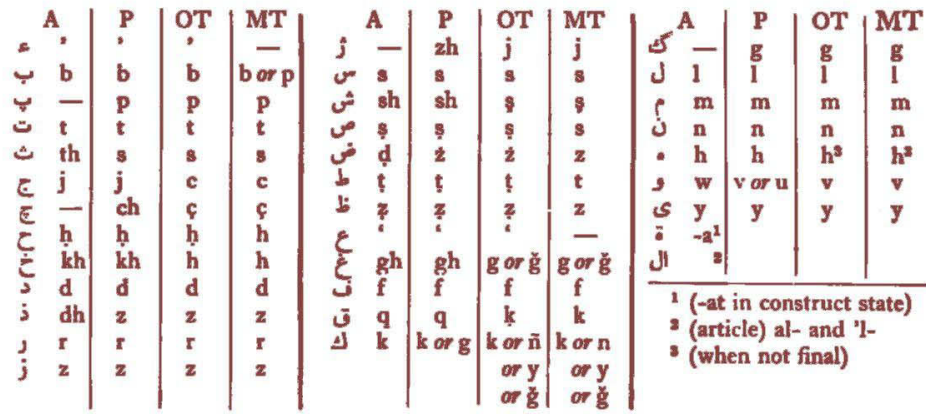

\section{VOWELS}

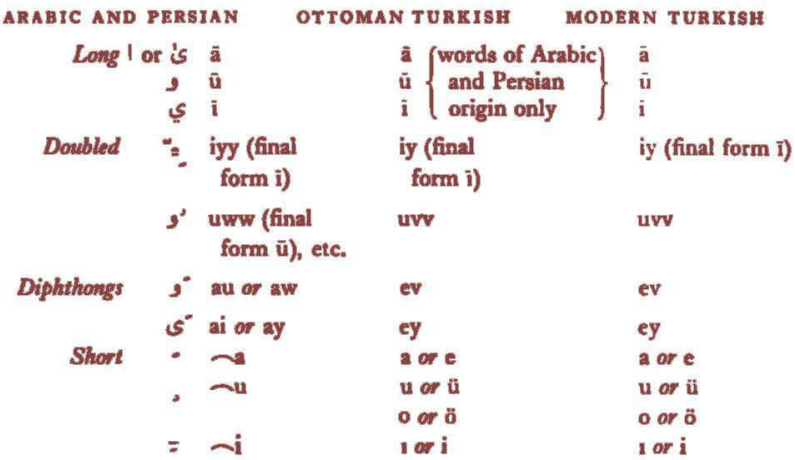

For Ottoman Turkish, authors may either transliterate or use the mudern Turkish orthngraphy.

Notes should be numbered consecutively and grouped together at the end of the text. They should be typed paragraph style (each new note begins a new paragraph), double-spaced between lines as well as between entries. The style of citations in notes should conform with the following examples:

1 E. Ashtor, A Social and Economic History of the Near East in the Middle Ages (Berkeley, 1976), pp. 29-31.

2 S. D. Goitein, A Mediterranean Society, Vol. 1, Economic Foundations (Berkeley, 1967), p. 193.

3 Bruce M. Russett, "Delineating International Regions," in J. David Singer, ed., Quantitative International Politics (New York, 1968), pp. 45-68.

4 B. Shoshan, "Grain Riots and the "Moral Economy" in Egypt 1350-1517," Journal of Interdisciplinary History, 10, 3 (Winter, 1980), 459-478.

When references to the same work follow without interruption use ibid. When references to the same work follow after interruption by other notes, use the author's last name and a short form of the title.

Figures (charts, graphs, and other artwork) should be in camera-ready form; they cannnot be redrawn by the printer. Captions should be provided, and preferred placement of figures indicated in manuscript.

Copyediting and proofreading. The publishers reserve the right to copyedit and proof all articles accepted for publication. Authors will review their copyedited manuscripts only if changes have been substantial. Page proofs of articles will be sent to authors for correction of typographical errors only.

General. Authors receive $\mathbf{5 0}$ offprints of their article without charge: additional copies may be purchased if ordered at proof stage. Submission of an article implies that it has not been published elsewhere. Authors are responsible for obtaining written permission to publish material for which they do not own the copyright. Contributors will be asked to assign their copyrights, on certain conditions, to Cambridge University Press. Books for review should go to the Review Editor for the appropriate subject area (see inside front cover for addresses), or they may be sent to the Editor (Peter von Sivers, Middle East Center, University of Utah, Salt 


\section{CONTENTS}

Marvin G. Weinbaum Dependent Development and U.S. Economic Aid to Egypt

Trmur Kuran The Economic System in Contemporary Islamic Thought: Interpretation and Assessment

Abraham Marcus Privacy in Eighteenth-Century Aleppo: The Limits of Cultural Ideals

Terrance G. Carroll. Islam and Political Community in the Arab World

Estelle Whel.AN The Origins of the Mihräb Mujawwaf: A Reinterpretation

Book Reviews

225-258

\section{The Middle East Studies Association of North America, Inc.}

This association was founded in 1966 in order to promote high standards of scholarship in the field of Middle Eastern Studies and to facilitate communication among scholars through metetings and publications. In addition to sponsoring the Journal, which is published for the Association by the Cambridge University Press, MESA publishes a Bulletin periodically, holds an Annual Conference, and provides other professional services for its members from time to time. Individuals interested in becoming members should write to: Headquarters and Secretariat, Department of Oriental Studies, University of Arizona, Tucson, AZ 85721. Fees are as follows: Full and associate members $\mathbf{\$ 5 0 . 0 0}$; students $\$ \mathbf{2 5 . 0 0}$. Fee includes subscription to International Journal of Middle East Studies, and to the MESA Bulletin and MESA Newsletter.

Members of the British Society for Middle Eastern Studies may subscribe to International Journal of Middle East Studies at a special rate of two-thirds of the present regular subscription price. Enquiries concerning membership in BRISMES should be sent to the Secretary, Dr. D. Hopwood. St. Antony's College, Oxford, England.

\section{Notes for Contributors}

Contributions and Editorial Correspondence should be sent to the Editor, Peter von Sivers, Middle East Center, University of Utah, Sait Lake City, Utah 84112. Authors should reserve one full copy of their manuscript for use in correcting proofs. Articles must be in English, should not exceed 12,000 words, and should be accompanied by a short summary. Spelling, capitalization, and punctuation must be consistent within each article and conform with the latest edition of A Manual of Style (University of Chicago Press).

Preparation of Manuseript. A title page should be prepared carrying the article title, auxiliary short title (not over $\mathbf{5 0}$ characters), author's full name (in the form preferred for publication), and author's affiliation (including mailing address). The entire manuseript (including notes) should be typed double-spaced on $81 / 2 \times 11$ inch or A4 paper, with margins set to accornmodate 70 characters per line and 25 lines per page, and should not exceed 43 typed pages. Manuscript pages should be numbered corisecutively.

Loanwords and Foreign Words. Loanwords (accepted English words such as ulama, alim, Shi' ite, sheikh, qadi, Sunni, and others) should be spelled in accordance with the first choice presented in Webster's Third New International Dictionary. Foreign words (not yet loanwords) must conform with the Journal's transliteration system; they should be italicized and defined at first use (and not italicized thereafter). Diacritics, except for ains and hamzas, should be omitted except where they are imperative to the argument. Authors who do use diacritics and transliteration have the total responsibility for consistency and accuracy in manuscript.

(continued inside back cover)

\section{CAMBRIDGE UNIVERSITY PRESS}

The Pitt Building, Trumpington Street, Cambridge CB2 IRP. England

32 East 57th Street, New York, NY 10022, U.S.A.

10 Stamford Road,. Oaldeigh, Melbourne 3206, Australia 